\title{
A Study on the Impact of Mainland Structural Reform on Cross-strait Economic and Trade Exchanges*
}

\author{
Yonghui $\mathrm{Xu}$ \\ Shandong Institute of Financial Development \\ Shandong University of Finance and Economics \\ Jinan, China
}

\begin{abstract}
This paper inspects the effects of structural reforms of the mainland on the cross-strait economic and trade exchanges between 1995 and 2014. The research focuses on four fields: the institutional reform, the reform of the financial sector, the reform of the labor market, and the reform of the trading sector. The main conclusions are as follows: (1) The mainland's structural reforms have brought significant positive effect on cross-strait trade and the direct investment from Taiwan to the mainland, among which the reform of mainland's financial sector, dominated by banking ownership reform and interest rate control, has the greatest impact; (2) Compared with the mainland's trade sector reform, the Cross-strait Economic Integration has more effectively closed the cross-strait economic and trade ties; (3) The role of institutional integration since 2010 in promoting the cross-strait economic ties needs further elaboration. The conclusions of this paper can provide enlightenments, including seizing the opportunity of structural reform of the supply side of the mainland to strengthen crossstrait economic ties, the reform process should give consideration to the guidance of the investment from Taiwan to the mainland, and deepening the economic integration of the two sides under the new situation.
\end{abstract}

Keywords-structural reform; supply-side; cross-strait; invest

\section{INTRODUCTION}

Economic and trade exchanges between the two sides of the Strait began to advance rapidly in the early 1990s. By 2003, the mainland had become Taiwan's largest trading partner and the largest investment destination for Taiwanese businessmen. However, as the economic structure of the two sides of the strait converges day by day and the mainland economy enters the new normal and other factors, the traditional mode of cross-strait economic and trade cooperation is facing adjustment in recent years, and the pace of cooperation is obviously slowing down. The adverse effects brought about by the change of political situation in Taiwan in 2016 are even more urgent for cross-strait economic and trade cooperation. This paper holds that in order to strengthen cross-strait economic cooperation in the new situation, more attention should be paid to the changes in the mainland, especially the opportunities and challenges brought about by the structural reforms in the mainland. Since

*This paper is funded by the general project of the National Social Science Foundation of China in 2017, "Research on Theoretical Innovation and Path Selection for supply-side structural reform towards Middle and High Level (Approval number: 17BJL032)".
1978, reform has been the main line running through the economic development of the mainland. The supply-side structural reform proposed in 2015 has had a profound impact on all areas of the mainland, and which has become the key for the mainland to cross the middle-income trap and realize the transformation of the economic development mode. According to the exposition of the 19th Congress, the next five years will be the transition period of China's economy from high speed growth to high quality development, and the change of core tasks will also bring about the change of emphasis of structural reform in various fields. In this context, to deepen cross-strait economic cooperation, it is necessary to clarify how structural reforms in various fields will affect cross-strait trade and investment relations, which is a prerequisite for Taiwan businessmen to better cut into the process of mainland reform.

\section{RELATED LITERATURE REVIEW}

\section{A. The Connotation of Structural Reform}

Structural reforms include policies to liberalize markets and policies to address market failures. The early structural reforms in the mainland were mainly demand-side, which focuses on stimulating the role of the three carriages of investment, consumption and exports to the economy. Since 2007, China's economic growth has declined and gradually entered the new normal, but the traditional demand stimulus has had little effect. Under this background, the demand for supply-side structural reform rises gradually, trying to solve the mismatch between supply and demand, adjust the economic structure, and raise the potential economic growth rate and employment rate. The innovation and development strategy proposed in recent years, "Internet + ", "made in China 2025" and the transformation of government functions all belong to supply-side reform. It can be said that these years are a transition period from the demand side to the supply side of the continent's structural reforms. But in essence, supply-side and demand-side reform is not the relationship between who comes first and who comes after, but should focus on the specific economic background and work together to push forward the overall structural reform. Although supply-side reforms are more vocal at the moment, demand-side reforms on the mainland continue to deepen, such as in the area of public goods construction. 
From the perspective of driving factors, there are three main incentives for structural reform: first, all kinds of crisis events. From a theoretical point of view, when faced with deteriorating economic conditions or economic turmoil, economies tend to implement structural reforms to boost the economy, known as the "crisis-spawning-reform hypothesis" (Drazen) According to the existing studies, Abdul Abiad and AshokaMody (2005) Luca Agnelloetet. al. (2015) all empirically support the crisis events drive for structural reform. Second, the demands of economic growth drive structural reforms. For example, a sharp decline in domestic demand will promote the implementation of trade liberalization reforms; reviewing the course of demand-side and supply-side structural reforms in mainland China also supports the phenomenon that demand for economic growth will push back structural reforms. Third, external factors, internal politics of the economy may also be an incentive to explain structural reforms. External aid, globalisation, and fighting among interest groups within economies can affect the implementation of structural reforms.

\section{B. Review of Relevant Research Papers on Structural Reform}

Since the 1990s, the academic research on structural reform has mainly included three aspects: the impact of various structural reforms on the macroeconomic performance of the economy, the combination effect of structural reform, and the implementation order of structural reform. The first aspect is the main body of the research on structural reform, including the impact on economic growth, economic convergence, foreign economic and trade exchanges and so on, as well as the analysis of influence channels and short-term and long-term effects. The second and third aspects of the research are relatively few, but the growth in recent years is very fast, which has an important guiding significance to promote the implementation of structural reform.
This paper focuses on the impact of structural reform on cross-strait economic and trade relations, which belongs to the first aspect of research. In theory, the successful implementation of structural reforms in host countries can reduce investment and operational risks and thus be viewed as a positive signal by foreign investors; Structural reform can bring more practical benefits to investors by facilitating investment, allocating resources more effectively and stimulating domestic demand; further, structural reforms can also enhance the absorbability of host countries to FDI inflows and promote the effective landing of direct investment There are many related studies abroad, but there are only a few domestic studies on the relationship between mainland structural reform and cross-strait economic relations, all of which are qualitative analysis, such as Zhu Lei (2017) qualitative analysis of supply-side structural reform in the mainland. The new driving force for Taiwanese businessmen to cultivate deep in the mainland includes joint research and development, structural reforms on the supply side of agriculture in the mainland, and opening up the high-end domestic demand market in the mainland.

\section{Model SETting AND DATA SElEction}

\section{A. Trade Gravity Model}

Tinbergen (1962) proposed the trade gravity model for the first time, that is, the amount of trade between economies depends on their economic size and geographical distance. In the empirical research, scholars gradually incorporate other factors such as population, regional economic integration and the use of common language into the model. We use this model to explain cross-strait trade and examine the impact of mainland structural reform by incorporating structural reform indicators.

The gravity model set in this paper belongs to the time series model, and its basic forms are as follows:

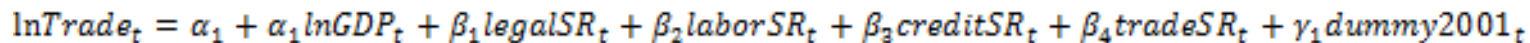

$$
\begin{aligned}
& +\gamma_{2} \text { dummy } 2010_{t}+\mu_{t}
\end{aligned}
$$

For an explanation of each variable in form (1), see "Table I", where we explain only the reasons for the inclusion of two virtual variables. According to Cao Xiao-heng et al. (2017), the entry of the two sides into WTO in 2001 and 2002 may be regarded as an indirect economic and trade liberalization policy between the mainland and Taiwan, and the Framework Agreement on Economic and Trade Cooperation between the two sides of the Taiwan Strait in 2010, (ECFA) is the starting point of cross-strait institutional cooperation. These two time points are important turning points for cross-strait economic and trade exchanges. If we ignore this change, we may attribute the impact of cross-strait economic integration on cross-strait economic and trade exchanges to the impact of the mainland's structural reform, thus overestimating the reform effect.

\section{B. FDI Determinant Model}

According to data released by the Taiwan Investment Review Commission, Taiwan approved 37 times more investment in the mainland in 2016 than the mainland's investment in Taiwan, so for the time being, a simple examination of the impact of structural reform on Taiwan's investment in the mainland is sufficient to draw a realistic conclusion. Here we only use Taiwan to approve investment in the mainland $\left(\operatorname{lnlaborm}_{t}\right)$ to reflect cross-strait investment relations.

According to the investment motivation, the main reasons for investors to choose investment location can be divided into market seeking type and resource seeking type. For the former, the host country's larger market size and good economic growth prospects play a key role in the inflow of FDI; for the latter, the host country's rich natural resources such as land, labor, natural gas, oil and so on will attract more FDI inflows. In the past two decades, the direct investment of Taiwan businessmen to the mainland has gradually changed from resource seeking to market seeking. Here we include these two factors as the traditional determinants of Taiwan businessmen investment in the mainland, that is, using the mainland's GDP represent market size $\left(\operatorname{lnGDPm}_{\mathrm{t}}\right)$, logarithm 
of the mainland's labor force $\left(\operatorname{lnlaborm}_{t}\right)$ to represent the mainland's natural resource affluence.

$$
\begin{gathered}
\ln F D I_{t}=\alpha_{1}+\alpha_{1} \operatorname{lnGDPm}_{\mathrm{t}}+\alpha_{2} \text { lnlaborm }_{\mathrm{t}}+\beta_{1} \text { legalSR }_{\mathrm{t}}+\beta_{2} \text { laborSR }_{\mathrm{t}}+\beta_{\mathrm{a}} \text { creditSR }_{\mathrm{t}}+\beta_{4} \text { tradeSR }_{\mathrm{t}}+\gamma_{1} \text { dummy2001 } \\
+\gamma_{2} \text { dummy } 2010_{\mathrm{t}}+\mu_{\mathrm{t}}
\end{gathered}
$$

\section{Data Sources and Processing Methods}

Specific data sources and processing methods are shown in "Table I". Here we only elaborate on the source of the mainland's structural reform indicators. Mainland structural reform indicators come from "Economic Freedom of the World (EFW)" (2016AnnualReport). The book sets up a set of index system of global economic liberalization from government scale, legal system and property right, agreed currency, international trade liberalization and supervision, the five fields are divided into 24 sub fields. Indicators for each area and sub-area range from 0 to 10 , and the higher the value is, the more liberalized the economy is in this area. In view of the scarcity of the existing structural reform indicators and the wide coverage of the EFW indicator system, this set of indicators has been used as a proxy for national economic policy in many empirical studies.

Given the availability of data on the mainland's structural reforms and the characteristics of cross-strait economic and trade exchanges, we will set the research period for 19952014.

\begin{tabular}{|c|c|c|c|c|}
\hline & Index & Variables used & Process mode & $\begin{array}{c}\text { Source } \\
\end{array}$ \\
\hline Cross strait trade & lnTrade & $\begin{array}{l}\text { Total volume of import and export trade across } \\
\text { the Taiwan Strait (millions of US dollars) }\end{array}$ & Take the logarithm & $\begin{array}{l}\text { Department of Taiwan, Hong Kong } \\
\text { and Macao, Ministry of } \\
\text { Commerce, mainland }\end{array}$ \\
\hline $\begin{array}{l}\text { Cross-strait investment } \\
\text { exchanges }\end{array}$ & $\operatorname{lnFDI}$ & $\begin{array}{l}\text { Taiwan approves investment in mainland China } \\
\text { (millions of US dollars) }\end{array}$ & Take the logarithm & $\begin{array}{l}\text { Taiwan Investment Review } \\
\text { Commission }\end{array}$ \\
\hline $\begin{array}{l}\text { Cross-strait economic } \\
\text { scale }\end{array}$ & $\operatorname{lnGDP}$ & $\begin{array}{l}\text { Product terms of nominal GDP in mainland and } \\
\text { Taiwan(millions of US dollars) }\end{array}$ & Take the logarithm & UNCTADstat \\
\hline $\begin{array}{l}\text { Mainland economic } \\
\text { scale }\end{array}$ & $\operatorname{lnGDPm}$ & Mainland nominal GDP(millions of US dollars) & Take the logarithm & UNCTADstat \\
\hline $\begin{array}{l}\text { Continental natural } \\
\text { resource affluence }\end{array}$ & lnlaborm & Total mainland labour force(Millions of people) & Take the logarithm & the World Bank \\
\hline $\begin{array}{l}\text { Mainland institutional } \\
\text { reform }\end{array}$ & legalSR & LegalSystem\&PropertyRights & & EFW \\
\hline $\begin{array}{l}\text { Labour sector reform on } \\
\text { the mainland }\end{array}$ & laborSR & Labormarketregulations & & EFW \\
\hline $\begin{array}{l}\text { Financial sector reform } \\
\text { on the mainland }\end{array}$ & creditSR & Creditmarketregulations & & EFW \\
\hline $\begin{array}{l}\text { Mainland trade sector } \\
\text { reform }\end{array}$ & tradeSR & Freedomtotradeinternationally & & EFW \\
\hline \multirow[t]{2}{*}{$\begin{array}{l}\text { Cross-strait economic } \\
\text { integration }\end{array}$} & dummy2001 & Dummy variable & $\begin{array}{l}\text { Assigned to } 0 \text { for } \\
1995-2000 ; 2001- \\
2014 \text { assigned to } 1\end{array}$ & Self-construction \\
\hline & dummy2010 & Dummy variable & $\begin{array}{l}1995-2009 \text { assigned } \\
\text { to } 0 ; 2010-2014 \\
\text { assigned to } 1\end{array}$ & Self-construction \\
\hline
\end{tabular}

TABLE I. DATA Source TABLE

\section{EMPIRICAL RESULTS BASED ON PARTIAL LEAST SQUARES}

Because the research period of this paper is short and there is a strong correlation between structural reform indicators, it is difficult to obtain effective estimation results by using OLS. In this paper, partial least squares (Partial Least Squares Regression, PLS) is used for empirical analysis.

\section{A. PLS Estimation Results of Trade Gravity Model}

Firstly, the optimal number of potential factors is determined by cross-validation and one potential factor is extracted from seven potential factors by PLS ${ }^{1}$. By using the

Cross-validation will select potential factors that can produce the highest predicted R2. extracted potential factor, the standardized coefficient estimates obtained by PLS regression are shown in the second column of "Table II" 2 . Obviously, cross-strait economic scale has the greatest impact on cross-strait trade, and the estimated coefficient is 0.192. Secondly, the financial sector reform, labor market reform, dummy 2001 policy virtual variables, while institutional reform, trade liberalization reform, dummy 2010 virtual variables have less impact.

"Table II", the third column gives the importance index VIP of variable projection. ${ }^{3}$ It can be seen intuitively that the

The normalized coefficient estimates exclude the influence of the dimension of independent variables and can be directly compared to obtain the information of the effect size of each variable.

3 The VIP (Variable Importance in Projection) index reflects the importance of each independent variable in explaining the dependent variable 
VIP value of cross-strait economic scale, financial sector reform, labor market reform, virtual variable dummy 2001 is higher than 1, and the VIP value of institutional reform index is close to 1; The VIP value of the mainland trade liberalization reform is around 0.9 , and the VIP value corresponding to the fictitious variable dummy 2010 is slightly higher than 0 . 8. Furthermore, from the standard coefficient estimation, the influence of each variable is consistent with the order of VIP value. This means that the mainland structural reform indicators and other control variables selected in this paper are important and meaningful to explain cross-strait trade.

TABLE II. PLS REGRESSION COEFFICIENT AND VIP VALUE

\begin{tabular}{l|l|l|l|l}
\hline \multicolumn{1}{c|}{ Variable } & \multicolumn{2}{|c|}{ Trade Gravity Model } & \multicolumn{2}{c}{ FDI Determinant Model } \\
\hline $\begin{array}{c}\text { Estimated } \\
\text { value of } \\
\text { standardized } \\
\text { coefficient }\end{array}$ & $\begin{array}{c}\text { The VIP } \\
\text { value of the } \\
\text { first latent } \\
\text { factor }\end{array}$ & $\begin{array}{c}\text { Estimated } \\
\text { value of } \\
\text { standardize } \\
\text { d coefficient }\end{array}$ & $\begin{array}{c}\text { The VIP value } \\
\text { of the first } \\
\text { latent factor }\end{array}$ \\
\hline legalSR & 0.1598 & 0.966 & 0.1334 & 0.959 \\
\hline creditSR & 0.1752 & 1.059 & 0.1432 & 1.030 \\
\hline laborSR & 0.1735 & 1.049 & 0.1362 & 0.980 \\
\hline tradeSR & 0.1476 & 0.892 & 0.1314 & 0.945 \\
\hline $\ln$ GDP & 0.1920 & 1.161 & & \\
\hline $\ln$ GDPm & & & 0.1512 & 1.087 \\
\hline $\ln l a b o r m$ & & & 0.1605 & 1.154 \\
\hline Dummy2001 & 0.1696 & 1.025 & 0.1475 & 1.061 \\
\hline Dummy2010 & 0.1331 & 0.805 & 0.1012 & 0.727 \\
\hline R2 & 0.955 & & 0.921 & \\
\hline
\end{tabular}

a. Source: author arranges himself.

\section{B. PLS Estimation Results of FDI Determinant Model}

The estimated results of the FDI determinant model (2) are shown in the fourth and fifth columns in "Table II". PLS extracted one latent factor from eight latent factors, which could explain $74.6 \%$ variation of independent variables and $92.1 \%$ variation of dependent variables. First of all, both the size of the mainland economy and the labor resources have played an important role in attracting Taiwanese businessmen to invest in the mainland, but from the estimation of the coefficient and the VIP value, the labor resources have a greater impact on explaining the inflow of Taiwanese capital, and statistically more important, this means that Taiwan's direct investment in mainland China during the $1995-2014$ is more of a resource seeking type. Secondly, the coefficient estimates of the four kinds of structural reform indicators have little difference, but compared with the reform of other sectors, the reform of the mainland financial sector plays a more important role in attracting Taiwan capital.

\section{Analysis of Estimated Results}

First, the measurement model based on the traditional international trade theory is applicable to cross-strait economic and trade issues. From the effect of model fitting, the determinant coefficient of trade gravity model and FDI determinant model are 0.955 and 0.921 respectively. Meanwhile, the traditional independent variables such as economic scale and resource endowment also play a key role

group, and the larger value indicates that the variable is more important, in general, when the VIP value is greater than 0.8 , the independent variable is considered to be important for the interpretation of the dependent variable set. in cross-strait trade and investment. It shows that the model we built on the premise of taking into account the characteristics of cross-strait economic and trade contacts has captured the cross-Strait economic and trade situation.

Second, the four types of mainland structural reforms have played a significant positive role in cross-strait economic and trade exchanges. From the symbol of the coefficient estimate, the four types of structural reforms have a positive impact on both cross-strait trade and Taiwan's approval of mainland investment, and the corresponding VIP values are higher than 0.8 .

In order to investigate the relative influence of various structural reforms, the ranking comparison of standardized regression coefficients is given in "Table III". Obviously, for cross-strait trade and Taiwanese investment, the relative influence brought by various structural reforms on the mainland is the same, which to some extent stems from the complementary relationship between cross-strait trade and investment. Specifically, the impact of the reform of the mainland's financial market, which is represented by the credit market supervision index, is the greatest, it shows that Taiwanese businessmen are more concerned about the improvement of the mainland financial system in order to better spread risk, allocate capital and achieve the actual landing of investment. The impact of labor market reform and institutional reform is the second, and the impact of mainland trade sector reform on cross-strait economic and trade exchanges is the least. This means that structural reforms on the mainland, like those in other developing economies, provide a positive signal to foreign investors, especially in the financial sector.

In order to further understand which areas of financial reform are more important, this paper uses three subindicators of credit market regulation in EFW-bank ownership, private sector credit, interest rate control-instead of regulatory indicators. Put in model (1) and model (2) re-estimate ${ }^{4}$. The estimated results show that mainland bank ownership reform and interest rate control have a strong positive effect on crossstrait economic and trade exchanges, but liberalization of the private credit market has a negative effect. However, this negative effect does not actually hinder cross-strait economic and trade exchanges from the estimation of coefficient and VIP value. The symbol, coefficient estimate and relative size of other variables are consistent with "Table II".

TABLE III. COMPARISON OF INFLUENCE RANKING OF STRUCTURAL REFORM INDEXES

\begin{tabular}{l|l|l}
\hline \multicolumn{1}{c|}{ Variable } & \multicolumn{1}{|c}{ Model (1) } & \multicolumn{1}{c}{ Model (2) } \\
\hline legalSR & $3(8.80 \%)$ & $3(6.83 \%)$ \\
\hline creditSR & $1(0)$ & $1(0)$ \\
\hline laborSR & $2(0.94 \%)$ & $2(4.86 \%)$ \\
\hline tradeSR & $4(15.8 \%)$ & $4(8.23 \%)$ \\
\hline
\end{tabular}

a. Note: Parentheses are based on the coefficient estimates of financial sector reform, the difference between the estimated coefficient of other structural reform indicators and the financial sector is calculated. For example, the difference between the estimated coefficient value of the financial sector reform index and that of the institutional reform index is $0.0154(0.175158$ minus 0.159751$)$, divided by 0.175 of the estimated coefficient of the financial sector, we can get $8.80 \%$.

Space limit, no longer listed here. If necessary, please ask for it from the author. 
Third, the impact of mainland trade sector reform index and two virtual variables of economic integration are compared. First of all, the impact of the virtual variable dummy 2001 on cross-strait economic and trade exchanges has always been greater than that of dummy 2010, which reflects that by 2014, the impact of ECFA on cross-strait economic and trade exchanges has not been brought into full play, less than the effect of the indirect economic and trade liberalization policy reached after China's accession to the WTO. This is consistent with Cao Xiaoheng et al. (2017)'s calculation of the level of cross-strait economic integration. From 2010 to 2014, cross-strait economic integration was in a high and steady upward trend, but its progress was far less than the rapid upward trend in the latter years of 2001. Secondly, the influence of virtual variable dummy2001 on cross-strait trade and investment is greater than that of tradeSR. This is in line with reality. Compared with other economies, the mainland has offered more preferential economic and trade policies to Taiwan. In addition, there are many similarities between the two sides of the strait that share the same roots. The virtual variable dummy 2001 captures the impact of this regional economic integration on cross-strait economic and trade exchanges. This discovery provides theoretical support for further strengthening the regional economic integration between the two sides of the strait and for closer economic ties between the two sides of the strait.

\section{CONCLUSION}

Based on the traditional international trade theory and the characteristics of cross-strait economy and trade, this paper constructs a trade gravity model and a FDI determinant model to examine the determinants of cross-strait import and export trade and Taiwan businessmen's direct investment in the mainland from 1995 to 2014. The innovation of the article is to introduce structural reform factors which were born in Taiwan outward and were born in the mainland inside. In the next few years, the mainland's structural reform will still focus on the supply-side trend from the demand side. The transformation of the key areas of reform will create new opportunities for cross-strait economic and trade cooperation, and lead cross-strait trade and investment to a new stage. This paper holds that the research on this aspect under the background of supply-side structural reform on the mainland has important practical significance for deepening cross-strait economic cooperation in the future. Based on the conclusions of the empirical research in this paper, we can draw the following enlightenment:

First, we should seize the opportunity of supply-side structural reform on the mainland to strengthen economic integration between the two sides of the strait.

The implementation of supply-side structural reform aims at adjusting the economic structure and realizing long-term sustainable economic growth under the new normal state. With the development of supply-side structural reform on the mainland, with the help of the favorable legal environment, business environment and many development opportunities, the economic integration between the two sides of the Taiwan Strait should enter a deeper stage. For example, at present, the driving force of innovation has become an important engine for the adjustment of the mainland's economic structure and industrial upgrading; the report of the 19th National Congress of the CPC also pointed out that innovation is the first driving force for leading development and the strategic support for building a modern economic system. In this atmosphere, Taiwanese businessmen should strengthen their investment in science and technology innovation and new industries.

Second, the reform process should be taken into account to promote Taiwan investment.

From Taiwan's approval of investment in the mainland, the structural reform of the mainland has indeed sent a positive signal to Taiwan. But from the mainland's actual use of Taiwan investment, this investment has not been fully absorbed by the mainland. According to the relevant data released by the Taiwan, Hong Kong and Macao Department of the mainland's Ministry of Commerce and the Taiwan Investment Review Commission, there is no match between Taiwan's approval of investment in the mainland and the actual use of Taiwan capital by the mainland. Before 2000, the mainland actually used more Taiwan capital than Taiwan approved for investment in the mainland. That is to say, Taiwan businessmen invest in the mainland from third parties, but after 2000 the former is larger than the latter, and this gap tends to widen, reflecting the gap between the strong willingness of Taiwanese businessmen to invest in the mainland and their ability to achieve it. Know the actual cause on the one hand, the capital elements of the early mainland are relatively scarce, attracting investment has become the inevitable choice of provinces and cities, and Taiwanese businessmen have obtained a lot of super national treatment. However, with the opening up of the mainland financial market and the opening up of more investment and financing channels, the scarcity of funds is decreasing, and the relative importance of Taiwan investment is gradually declining. As mentioned above, it is found that the liberalization of private credit market has a negative effect on Taiwanese investment in the mainland. On the other hand, with the improvement of the mainland legal system and the cancellation of various preferential policies on Taiwan, it is necessary for Taiwan businessmen to transform and upgrade at the right time. However, many Taiwanese businessmen are unable to adapt to their new role, and many of them divestment. Under such circumstances, it is urgent for Taiwan businessmen to face up to the reality, to transform and upgrade, and at the same time, the mainland should provide guidance and services to Taiwan investment in the process of reform, so that Taiwanese businessmen can really integrate into the process of supplyside structural reform in the mainland.

\section{Third, deepen cross-strait economic integration}

The study finds that, compared with the mainland's foreign trade liberalization reform, the regional economic integration between the two sides of the Strait is more effective in closing the economic and trade links between the two sides of the Strait. However, at present, the progress of cross-strait economic integration is slowing down. Under this background, many scholars have put forward targeted suggestions on how to further deepen cross-strait economic and trade cooperation. These include driving a dynamic shift in economic 
cooperation between the two sides (Wang Yuan-yuan 2016), leading Taiwan enterprises to upgrade and develop the mainland market (Zhu Lei 2016) and building a cross-Strait industrial supply chain to build a community of destiny (Shan Yu-li 2017). This paper holds that how to fully implement the existing ECFA and its subsequent agreements in order to promote cross-strait economic integration from the economic level is the key under the situation that the institutional cooperation between the two sides of the strait is difficult to promote.

\section{REFERENCES}

[1] Drazen,A.,Grilli,V..Thebenefitofcrisesforeconomicreforms[J].American EconomicReview83(3), 1993:598-607.

[2] AbdulAbiad, Ashoka Mody. Financial Reform: What Shakes It? What Shapes It? [J] The American Economic Review,Vol.95, No.1(Mar.,2005), pp.66-88.

[3] Luca Agnello, Vitor Castro, Joao Tovar Jalles, Ricardo M.Sousa. What determines the likelihood of structural reforms? [J] European Journal of Political Economy, 37(2015): 129-145.

[4] Cao Xiaoheng, Li Yue, Xu Yonghui. A Comparative study on the Construction and comparison of the Measurement system of Economic Integration between the two sides of the Taiwan Strait [J]. Journal of Shanxi University of Finance and Economics, The second issue in 2017:1-11.

[5] Shan Yu-li. The influence of Macro-environment change on mainland Taiwan businessmen and the Choice of Development path [J]. AsiaPacific economy, The fourth issue in 2017:150-154.

[6] Wang Yuanyuan. Dynamic Transformation and path Choice of CrossStrait Economic Integration Development under the new normal [J].Fujian Forum. Humanities and Social Sciences Edition, The ninth issue in 2016: 176-183.

[7] Zhu Lei. Structural Reform on the supply side: a New driving Force for Taiwan businessmen to cultivate the Road [J]. Cross-strait relations, The fifth issue in 2017: 16.

[8] Zhu Lei. Cross-strait economic relations enter "new normal" [J]. AsiaPacific economy, the third issue in 2016: 137-142. 